
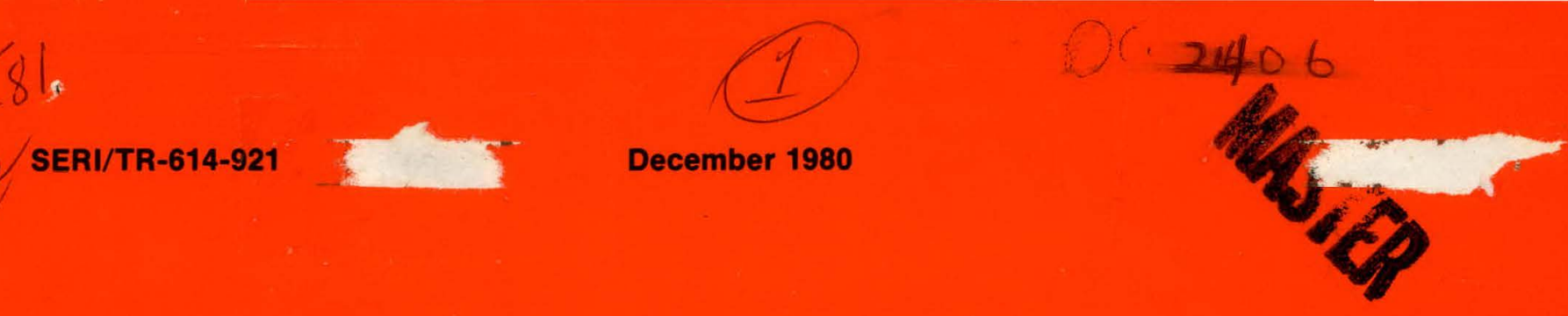

\title{
The Growth of Silicon Sheets for Photovoltaic Applications
}

Thomas Surek
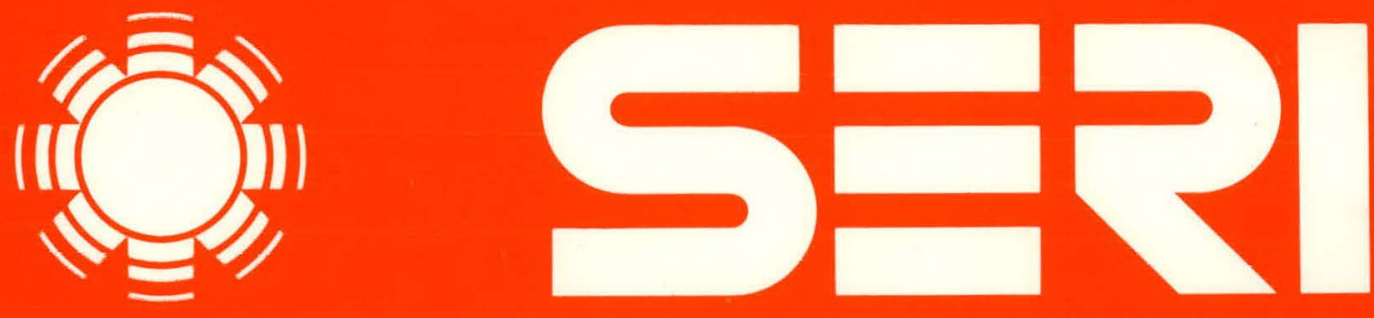

Solar Energy Research Institute

A Division of Midwest Research Institute

1617 Cole Boulevard

Golden, Colorado 80401

Operated for the

U.S. Department of Energy

under Contract No. EG-77-C-01-4042 


\section{DISCLAIMER}

This report was prepared as an account of work sponsored by an agency of the United States Government. Neither the United States Government nor any agency Thereof, nor any of their employees, makes any warranty, express or implied, or assumes any legal liability or responsibility for the accuracy, completeness, or usefulness of any information, apparatus, product, or process disclosed, or represents that its use would not infringe privately owned rights. Reference herein to any specific commercial product, process, or service by trade name, trademark, manufacturer, or otherwise does not necessarily constitute or imply its endorsement, recommendation, or favoring by the United States Government or any agency thereof. The views and opinions of authors expressed herein do not necessarily state or reflect those of the United States Government or any agency thereof. 


\section{DISCLAIMER}

Portions of this document may be illegible in electronic image products. Images are produced from the best available original document. 
Printed in the United States of America Available from:

National Technical Information Service

U.S. Department of Commerce

5285 Port Royal Road

Springfield, VA 22161

Price:

Microfiche $\$ 3.00$

Printed Copy $\$ 4.00$

\begin{abstract}
NOTICE
This report was prepared as an account of work sponsored by the United States Government. Neither the United States nor the United States Department of Energy, nor any of their employees, nor any of their contractors, subcontractors, or their employees, makes any warranty, express or implied, or assumes any legal liability or responsibility for the accuracy, completeness or usefulness of any information, apparatus, product or process disclosed, or represents that its use would not infringe privately owned rights.
\end{abstract}


THE GROWTH OF SILICON SHEETS

FOR PHOTOVOLTAIC APPLICATIONS

THOMAS SUREK

DECEMBER 1.980

Prepared UNDER TASK No. 3821.02

\section{Solar Energy Research Institute}

A Division of Midwest Research Institute

1617 Cole Boulevard

Giolden, Colorado 80401

Prepared for the

U.S. Department of Energy

Contract No. EG-77-C-01-4042 
THIS PAGE

WAS INTENTIONALLY LEFT BLANK 


\section{PREFACE}

This report is based on an invited presentation by the author in the Symposium on "Novel Silicon Growth Methods" at the 157th meeting of The Electrochemical Society held in St. Lou is, Missouri, on 11-16 May 1980. Proceedings of the symposium are to be published by The Electrochemical Society. The report presents a critical assessment of the various silicon sheet growth processes under development for low-cost terrestrial photovoltaics.

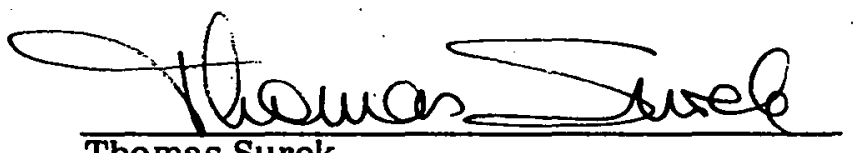

Thomas Surek

\section{Approved for}

SOLAR ENERGY RESEARCH INSTITUTE

1

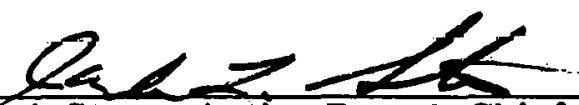

Jack Stone, Acting Branch Chicf

Photovoltaics Advanced Silicon Program

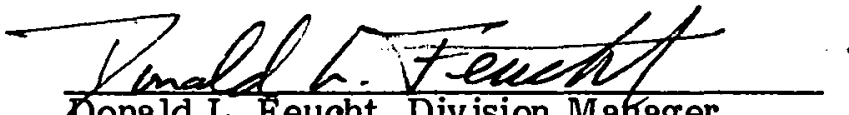

ठonald L. Feucht, Division Makager

Photovoltaics Division 


\section{THIS PAGE}

\section{WAS INTENTIONALLY}

: LEFT BLANK 


\section{SUMMARY}

Objective: Review and compare four "fast" ribbon, silicon sheet growth processesdendritic-web growth (WEB), edge-defined film-fed growth (EFG), ribbon-to-ribbon growth (RTR), and the silicon-on-ceramic process (SOC)-and identify some of the problems that need to be resolved.

Discussion: The potential to meet the low-cost objectives for terrestrial photovoltaics of a number of silicon sheet growth processes is nearly ready to be demonstrated. Silicon sheet growth processes are classified according to their linear growth rates. The "fast" growth processes are comparatively ranked subject to criteria involving growth stability, sheet productivity, impurity effects, crystallinity, and solar cell results. The status of more rapid silicon ribbon growth techniques, such as horizontal ribbon growth and melt quenching, is also reviewed. The emphasis of the discussion is on examining the viability of these sheet materials as solar cell substrates for low-cost silicon photovoltaic systems.

Conclusions: Although there is good reason to expect that the objectives to achieve lowcost silicon photovoltaic systems will be met, it is not possible to choose, in the author's opinion, a mong the various sheet growth processes at this time. This is especially true if one considers the results of the more rapid sheet growth techniques also reviewed in th is paper, or the results of other novel sheet growth approaches repor ted recently. 


\section{THIS PAGE}

\section{WAS INTENTIONALLY \\ LEFT BLANK}




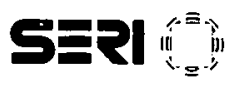

TR -921

TABLE OF CONTENTS

Page

1.0 Introduction

1

2.0 Comparison of "Fast" Ribbon Growth Techniques

2

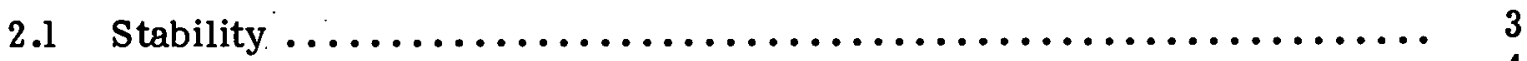

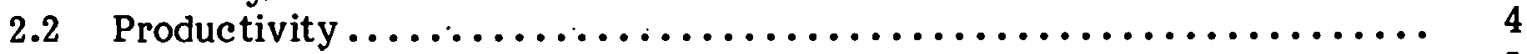

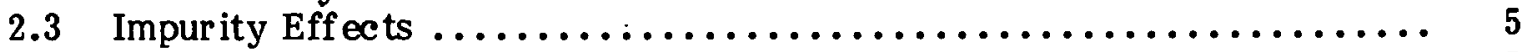

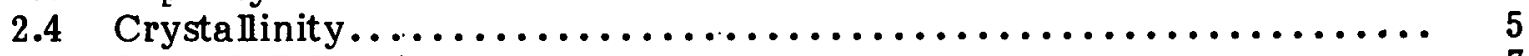

2.5 Solar Cell Results

3.0 Sta tu of "Faster" and "Fastest" Ribbon Growth Techniques

8

3.1 Horizon tall Ribbon Growth

8

3.2 Melt Quenching or Spinning

9

4.0 Summary

10

5.0 References

11

vii 
THIS PAGE

\section{WAS INTENTIONALLY \\ LEFT BLANK}




\section{HST OF FIGURES}

1 Classification of Silicon Sheet Growth Processes According to Linear Growth Rate $\ldots \ldots \ldots \ldots \ldots \ldots \ldots \ldots \ldots \ldots \ldots \ldots \ldots \ldots \ldots \ldots$

2 Comparison of "Fast" Sheet Growth Processes According to Growth Stability

3 Comparison of "Fast" Sheet Growth Processes Based on the Current Sta tus of Productivity Parameters ..........................

4 Comparison of "Fast" Sheet Growth Processes Based on the Effects of Impurities

5 Comparison of "Fast" Sheet Growth Processes Based on Considerations of Crystallinity

6 Comparison of "Fast" Sheet Growth Processes Based on the Current

Status of Solar Cell Results $\ldots \ldots \ldots \ldots \ldots \ldots \ldots \ldots \ldots \ldots \ldots \ldots \ldots \ldots \ldots$

7 Status of "Faster" Sheet Growth Processes $\ldots \ldots \ldots \ldots \ldots \ldots \ldots \ldots \ldots \ldots \ldots \ldots$

8 Status of Silicon Ribbon Growth by Roller Quenching $\ldots \ldots \ldots \ldots \ldots \ldots \ldots \ldots$ 
Blank

$x$ 


\section{SECTION 1.0}

\section{INTRODUCTION}

A variety of novel silicon crystal growth methods have evolved over the past few years in attempts to reduce the cost of silicon photovoltaic systems. Techniques to grow silicon sheets directly are especially attractive in that the slicing costs and material losses of conventional techniques are eliminated. This paper reviews the status of these novel growth methods and examines the advantages and limitations of the techniques from the points of view of growth stability, the potential to use low-cost silicon starting materials, the crystalline and photovoltaic quality of the silicon sheet, and the overall low-cost potential of the techniques.

Silicon solar cell substrates have been obtained directly from the melt in the form of both unsupported and supported sheets. The growth of sheet crystals from the melt relies on some for $m$ of control of the crystallization front through control of the temperature distributions in the crystal growth system, and, in some cases, through control of the liquid-vapor interface (or meniscus) shape. Precise control of the temperature distribution in the melt permits the crystallization of dendrites which support the thin, solidifying web in web-dendrite growth (denoted by WEB in this report). The use of a capillary die to control the shape of the meniscus reduces to some extent the thermal control requirements of edge-defined film-fed growth (EFG). In the ribbon-to-ribbon (RTR) process, a form of meniscus shape control is inherent; the ribbon on the feed side takes the place of the EFG die. In the rigid-edge RTR process, the stability is further enhanced because the sharp meniscus curvatures at the ribbon edges are eliminated. Horiz ontal ribbon growth techniques require precise control of the temperature distribution in the melt and of the cooling of the solidifying ribbon surface. In suppor ted-sheet techniques, the thermal control requirements are alleviated by the stabilizing effects of the supporting substrate on the meniscus shape. Silicon sheets have been grown on supporting substrates such as mullite by the silicon-on-ceramic (SOC) process and graphite by the ribbon-against-drop (RAD) process. Further discussion of the growth stability in these sheet growth processes is presented in later sections; detailed descriptions of the techniques can be found in the literature (Cullen and Surek 1980).

A characteristic of all sheet growth techniques is that the linear growth rates are much greater than the crystal growth rates in the conventional ingot growth techniques. A classification of sheet growth processes may be made on the basis of these linear rates, as shown in Fig. 1. The rapid growth rates result from the manner in which the latent heat of solidification is removed from the solid-liquid interface: In the "fast" growth techniques, the growth interface is essentially perpendicular to the crystal pulling direction; the high surface-to-volume ratio of the thin sheet crystal permits the effective removal of the latent heat, by radiative and convective processes, from the sheet surface (see schematic in Fig. 1). "Faster" growth rates can be obtained in horizontal ribbon growth processes, in which the solid-liquid interface is nearly parallel to the crystal puil ing direction. In the "fastest" ribbon growth tecliniques, the latent heat is removed very effectively by conduction to a rapidly rotating, cooled wheel.

The major part of this paper is concerned with the "fast" ribbon growth techniques which have received the most attention over the past few years and thus are considerably more advanced than the relatively novel horizontal ribbon growth or melt quenching techniques. Section 2.0 presents a comparison and a qualitative ranking of four of the processes (EFG, WEB, SOC, RTR) listed in Fig. 1; many of the conclusions reached about the SOC process should apply to the RAD process as well. Recent advances in silicon 


\begin{tabular}{l|l|l|l} 
"Fast" Ribbon Growth & $1-10 \mathrm{~cm} / \mathrm{min}$ & $\begin{array}{l}\text { EFG, WEB } \\
\text { SOC, RTR } \\
\text { RAD }\end{array}$ \\
\hline "Faster" Ribbon Growth & $10-100 \mathrm{~cm} / \mathrm{min}$ & & $\begin{array}{l}\text { Horizontal } \\
\text { Ribbon Growth }\end{array}$ \\
\hline "rástest" Rlbbull Growth & $\gg>100 \mathrm{~cm} / \mathrm{min}$ & S & $\begin{array}{l}\text { Melt Quenching } \\
\text { or Spinning }\end{array}$
\end{tabular}

\section{Figure 1. Classification of Silicon Sheet Growth Processes According to Linear Growth Rate}

Schematics show crystal pulling direction (straight arrows) and heat loss directions (wavy arrows).

sheets grown by the RAD process are described in the literature (Electrochemical Snciety 1980). The status of the "faster" and "fastest" ribbon growth techniques is reviewed in Section 3.0 .

\section{SEC:TION 2.0}

\section{COMPARISON OP "FAST" RIBBON GROWTH TECHNIQUES}

The criteria used to compare the "fast" ribbon gruwth techniqucs are: (1) stahility, (2) productivity, (3) impurity effects, (4) crystallinity, and (5) solar cell results. Included in each of these major criteria are several subcriteria as described below. Most of the information presented here is based on that available in the published literature; additional da ta was ob tained from various reports from U. S. Government-sponsored research. The author has also contacted euch of the organizations pursuing the research to obta in upto-date information on their processes, as well as their comments concerning the criteria used in the comparisons.

It should be noted that the criteria used in this paper are those of the author, and do not necessarily include all the criteria needed to judge these processes. The chosen criteria, however, emphasize the technical advantages and limitations of the various techniques, as well as help to identify some of the major problem areas that need to be resolved to atta in the low-cost objectives for terrestrial photovoltaics. The "rankings" which are presented are also those of the author; in many cases, they are based on subjective and so mewhat speculative considerations and may be disputed by the reader. 


\begin{tabular}{|c|c|c|c|c|c|c|}
\hline & Thermal Control & Menlscus Control & Interface Shape & $\begin{array}{l}\text { Thlekness/ } \\
\text { Width Control }\end{array}$ & $\begin{array}{l}\text { Continuous } \\
\text { Growth }\end{array}$ & Concerns . \\
\hline SOC & $\begin{array}{l}\text { Dlp-coat understood; } \\
\text { Active proheater; } \\
\text { Passive control } \\
\text { of temp. prolile; } \\
\pm 5-10^{\circ} \mathrm{C} \text { in trough }\end{array}$ & $\begin{array}{l}\text { Some understanding } \\
\text { of SCIM; } \\
\text { Growth stable at } \\
15-20^{\circ} \text { angle; } \\
\text { Some edge elfects }\end{array}$ & $\begin{array}{l}\text { Lateral very } \\
\text { important; } \\
\text { Asymmetric } \\
\text { growth possible }\end{array}$ & $\begin{array}{l}t=f(\text { velocity }) \\
50-200 \mu m ; \\
w=I(\text { substrate }) \\
\text { Good control }\end{array}$ & $\begin{array}{l}\text { Batch; } \\
\text { No automation; } \\
\text { Manual melt } \\
\text { level control }\end{array}$ & $\begin{array}{l}\text { Substrate cost; } \\
\text { Temp. uniformity; } \\
\text { Mech. design; } \\
\text { Nonwetting; } \\
\text { Automation }\end{array}$ \\
\hline RTR & $\begin{array}{l}\text { Tak understood; } \\
\text { Active pre/aflerheater; } \\
\text { Manual laser power } \\
\text { control; } \\
\text { Self stabilization }\end{array}$ & $\begin{array}{l}\text { Rigid edges } \\
\text { stabilize growih; } \\
\text { Melt shape/size } \\
\text { to be controlled }\end{array}$ & $\begin{array}{l}\text { Controlled with } \\
\text { laser scan and } \\
\text { power Input } \\
(w, 1)\end{array}$ & $\begin{array}{l}t=I(\text { feedstock }) \\
\pm 50 \mu \mathrm{m} ; \\
w=f\left(w_{\text {cen }}\right) \\
\pm 1 \mathrm{~mm}\end{array}$ & $\begin{array}{l}\text { Batch, some } \\
\text { semicontinuous; } \\
\text { Visual control } \\
\text { of melt shape }\end{array}$ & $\begin{array}{l}\text { Cost of laser } \\
\text { (Use e-beam?); } \\
\text { Aulomation; } \\
\text { Feedstock; } \\
\text { Stresses }\end{array}$ \\
\hline EFG & $\begin{array}{l}\text { Theory developed; } \\
\text { Active die (edge/ } \\
\text { face) heaters and } \\
\text { afterheater; } \\
\pm \text { few }{ }^{\circ} \mathrm{C} \text { in crucible }\end{array}$ & $\begin{array}{l}\text { Theory developed; } \\
\text { Meniscus height and } \\
\text { edge position controls; } \\
\text { Bulbous dies } \\
\text { slabilize edges }\end{array}$ & $\begin{array}{l}\text { Controlled with } \\
\text { die design and: } \\
\text { thermal elements } \\
(w, 1)\end{array}$ & $\begin{array}{l}t=f(\text { die }, . . .) \\
\pm 50 \mu \mathrm{m} ; \\
w=1 \text { (die) } \\
\pm 50 \mu \mathrm{m}\end{array}$ & $\begin{array}{l}\text { Yes; } \\
\text { Automation } \\
\text { developed; } \\
\text { Melt replenish }\end{array}$ & $\begin{array}{l}\text { Freezes; } \\
\text { Automated } \\
\text { growth initiation; } \\
\text { Stresses }\end{array}$ \\
\hline WEB & $\begin{array}{l}\text { Theory developed; } \\
\text { Passive control } \\
\text { of temp. proflle; } \\
\pm \text { few tenths }{ }^{\circ} \mathrm{C} \\
\text { in crucible }\end{array}$ & \multicolumn{2}{|c|}{$\begin{array}{l}\text { Studies based on heat flow; } \\
\text { Lateral profile very important; } \\
\text { Shaped radlation shields } \\
\text { provide passive control }\end{array}$} & $\begin{array}{l}t=f(\text { velocity }) \\
\pm \text { few } \mu \mathrm{m} ; \\
w=1\left(T_{\text {ment }}\right) \\
\text { Need melt } \\
\text { level control }\end{array}$ & $\begin{array}{l}\text { Some; } \\
\text { Melt level } \\
\text { control with } \\
\text { replenishment }\end{array}$ & $\begin{array}{l}\text { Pullouts; } \\
\text { Automation } \\
\text { (w, melt level); } \\
\text { Temp. control; } \\
\text { Stresses }\end{array}$ \\
\hline
\end{tabular}

\section{Figure 2. Comparison of "Fast" Sheet Growth Processes According to Growth Stability}

The ranking (top to bottom) is based on the best ultimate potential. The asterisk ( $\left(^{*}\right)$ denotes best potential in a given area.

\subsection{STABLITY}

One of the most important criteria for comparing sheet growth techniques is the stability of the growth process. Figure 2 lists the various suberiteria used for this comparison; the techniques are listed in order of the best ultimate potential, in the author's estimate. Areas where a given technique appears to have some advantages over the others are also indicated in the figure. The following discussion focuses on the most important points in the figure; the other entries should be self-explanatory.

The SOC process is likely to have the least sensitive thermal control requirements; researchers estimate that a $5^{\circ}$ to $10^{\circ} \mathrm{C}$ variation in temperature along the trough (i.e., the width of the sheet) should be tolerable. (In this discussion of the SOC process, it should be noted that the silicon coating by inverted meniscus or SCIM-coating technique, where a carbon-coated mullite substrate is passed over a trough containing molten silicon, is being considered.) Meniscus stability is obtained if the coating is carried out at an angle with respect to the horizontal of 15 to 20 degrees. In spite of the laxity of thermal control requirements, control of the lateral in terface shape is one of the major current concerns in the process. Interface shape control in the thickness dimension (i.e., asymmetric growth) may be required to achieve the high throughput rates for low cost. The thickness and width control data listed in Fig. 2 represent the state of the art; the SOC technique probably offers the best overall potential in this area. 
In the RTR process, the temperature profile in the solid is actively controlled by pre- and after-heaters, but the power input to the laser is controlled manually, based on visual observation. In terms of meniscus shape control at the ribbon edges, the rigid-edge R TR offers the most advantages; the stability will be further enhanced if automatic controls for the melt shape and size are developed. Appropriate control of the laser scan may also lead to control of the interface shape in the width and thickness dimensions.

The EFG technique probably has the best-developed theories of thermal and meniscus controls. Theoretical considerations have resulted in au to mated controls of the te mperature profile in the ribbon and of the meniscus height and ribbon edge positions. EFG also offers the best potential for direct control of the shape of the growth interface through appropriate designs of the die and of the active die-hea ter elements.

In the WEB technique, theoretical attention has focused on the temperature profiles in the melt and in the web crystal. These are passively controlled by the design of the radiation shields. Achievement and maintenance of the proper lateral temperature distribution in the melt is one of the major concerns to be resolved in this technique. Control of the melt level in the crucible, with continuous melt replenishment, should significantly allevia te the growth control problems.

Additional data are presented in Fig. 2 on the state of the art of thickness and width control and of the approaches to continuous growth. In the SOC and RTR techniques, the aim is to achieve semicontinuous growth (i.e., finite sheet leng ths). Finally, some of the major concerns for the various techniques are listed. A common concern for all the processes is the achievement of a high yield of suitable solar cell substrate materials at the high productivity rates required for low cost.

\subsection{PRODUCTIVTY}

'The ranking of sheet growth processes according to productivity criterla is shown in Fig. 3; this ranking is based on the current status of the technologles. The two sets of figures in the first three columns represent the best values achieved (on top) and the values routinely ob tained (on bottom) for the respective parameters. Many of the "best" values listed have been exceeded under non-steady-sta te growth conditions.

The fastest linear growth rates have been achieved with the SOC technique, while the widest sheets are consistently grown by EFG, where 5- or 10-cm-wide ribbons are grown routinely depending on the width of the die. The thinnest sheet is ob tained most consistently by the WEB technique. Thinner coatings could be achieved by SOC, but very likely at the expense of sheet quality for photovoltaic applications. In terms of continuous and multiple growth, as well as automation, EFG is the current leader among the sheet technologies. Multiple growth (i.e., simultaneous growth from the same crucible) of 5- and $10-\mathrm{cm}$-wide ribbons has been achieved, as indicated in Fig. 3. Automation is based on meniscus height and ribbon edge position controls. No appreciable deterioration of the graphite die was reported after the 15-hour growth experiment. Initial efforts at melt replenishment in the WEB technique have permitted growth over a 17-hour period, resulting in ribbon lengths of 3 to $4 \mathrm{~m}$; in addition, two web crystals (in separa te furnaces) were grown under the control of a single operator. Multiple growth has also been demonstrated in the RTR process.

The right-hand column in Fig. 3 lists the productivity goals for the various techniques. Simultaneous achievement of these goals is necessary to meet the low-cost silicon sheet objectives for terrestrial photovoltaics (i.e., a module price of $\$ 0.70 / \mathrm{W}_{\mathrm{p}}$ ). The 
parameters listed represent (top-to-bottom): linear or area growth ra te, sheet thickness, multiple growth requirements; and length of the growth cycle. The RTR process is envisioned to become semicontinuous, involving finite ribbon segments in a cassette-based operation. High yields of usable sheet material ( $290 \%$, depending on the process) are also required to meet the low-cost goals.

\subsection{IMPURITY EPPECTS}

The following aspects of impurity effects are considered in the process ranking: the potential sources of impurities, the possibilities to segregate and/or redistribute impurities during the growth process, and the potential to use a low-grade silicon feedstock in the process without detrimental effects on the growth. The ranking of the processes, based on the ultimate potentials of the techniques, is shown in Fig. 4.

In addition to the specific sources of impurities cited in Fig. 4, common sources of impurities for all the processes are the silicon feedstock and the furnace environment in which the growth is carried out. The WEB process, because it most closely approximates the conventional silicon growth methods, has the best potential from the point of view of impurity sources. The WEB process also permits the rejection of segrega ted impurities; in short growth runs, effective segregation coefficients $\left(k_{e f f}\right)$ somewhat higher than the equilibrium value have been found. Theoretical calculations predict that $k_{e f f}<1$ in long-term growth runs with continuous melt replenishment. Some purification should also be possible in the RTR process, at least over the initial portions of the recrystallized ribbon.

The redistribution of impurities can be controlled very effectively in the EFG process by appropria te designs of the capillary channels in the die; control of impurity redistribution has been demonstrated in both the width and thickness dimensions of the ribbon. The RTR and SOC techniques also offer, in principle, the potential for controlling the distribution of impurities through appropriate control of the shape of the growth interface.

Finally, in several of the techniques listed in Fig. 4, there has been some growth experience using an impure silicon feedstock, such as metallurgical-grade (mg) silicon. Qualitatively, it is expected that the effect on growth stability (e.g., constitutional supercooling) will decrease from WEB to SOC in the order indicated in the figure. The ultima te concern in using a low-grade silicon feedstock is the quality of the silicon sheet for photovoltaic applications. In this regard, it should be noted that only the WEB process results in some degree of purification $\left(k_{e f f}<1\right)$.

\subsection{CRYSTALLINITY}

In a comparison based on crystallinity criteria, it is clear that the WEB process has the best potential. It is the only sheet growth process which yields an essentially singlecrystal substrate with a mirror-like surface. The other techniques, as indicated in Fig. 5, yield essentially similar structures consisting mainly of twin boundaries parallel to the growth direction, and other defects. There is some possibility in these techniques for controlling the crystalline structure with appropriate control of the solid-liquid in terface shapes in the thickness and width dimensions. Such control has been demonstrated in both the EFG and RTR processes. In addition, control of furnace environment has been shown to affect the crystallinity of EFG ribbons, as discussed by Kalejs et al. (Electrochemical Society 1980). A major concern in all the unsupported sheet growth 


\begin{tabular}{|c|c|c|c|c|c|c|c|}
\hline & $\begin{array}{c}\text { Rate } \\
(\mathrm{cm} / \mathrm{min})\end{array}$ & $\begin{array}{l}\text { Width } \\
\text { (cm) }\end{array}$ & $\begin{array}{c}\text { Thickness } \\
(\mu \mathrm{m})\end{array}$ & $\begin{array}{l}\text { Continuous } \\
\text { Growth }\end{array}$ & $\begin{array}{l}\text { Multiple } \\
\text { Growth }\end{array}$ & Automation & $\begin{array}{l}\text { Low-Cost } \\
\text { Goals }\end{array}$ \\
\hline EFG & $\begin{array}{c}5 \\
2.5-4\end{array}$ & $5-10$ & $\begin{array}{l}150-200 \\
250-300\end{array}$ & $\begin{array}{l}5 \times 30-m \\
\text { lengths; } \\
15 \mathrm{~h}\end{array}$ & $\begin{array}{l}5 \times 5 \mathrm{~cm} \\
3 \times 10 \mathrm{~cm}\end{array}$ & $\begin{array}{l}\text { Yes; } \\
\text { Meniscus ht., } \\
\text { edge position }\end{array}$ & $\begin{array}{l}5 \mathrm{~cm} / \mathrm{min} \\
150 \mu \mathrm{m} \\
10 \times 10 \mathrm{~cm} \\
5 \text { days }\end{array}$ \\
\hline WEB & $\begin{array}{c}7 \\
3-4\end{array}$ & $\begin{array}{c}4.7 \\
3.5-4\end{array}$ & $\begin{array}{l}50^{*} \\
150^{*}\end{array}$ & $\begin{array}{l}3-4-\mathrm{m} \\
\text { lengths; } \\
17 \mathrm{~h}\end{array}$ & $\begin{array}{l}2 \text { per } \\
\text { operator }\end{array}$ & $\begin{array}{l}\text { Yes; } \\
\text { melt level, } \\
\text { replenishment }\end{array}$ & $\begin{array}{l}25 \mathrm{~cm}^{2} / \mathrm{min} \\
150 \mu \mathrm{m} \\
6 \text { per operator } \\
3 \text { days }\end{array}$ \\
\hline soc & $\begin{array}{l}15^{*} \\
4 \times 5\end{array}$ & $\begin{array}{l}10 \\
5\end{array}$ & $\begin{array}{l}100 \\
200\end{array}$ & $\begin{array}{l}50-\mathrm{cm} \\
\text { lengths }\end{array}$ & None: & None & $\begin{array}{l}350 \mathrm{~cm}^{2} / \mathrm{min} \\
100 \mu \mathrm{mm} \\
10 \times 2 \times 12.5 \mathrm{~cm} \\
5 \text { days }\end{array}$ \\
\hline RTR & $\begin{array}{c}9 \\
2.5-5\end{array}$ & $\begin{array}{l}7.5 \\
3.5\end{array}$ & $\begin{array}{c}100 \\
150-200\end{array}$ & $\begin{array}{l}30-\mathrm{cm} \\
\text { lengths }\end{array}$ & $\begin{array}{l}4 \times 1.3 \mathrm{~cm} \\
2 \times 5 \mathrm{~cm}\end{array}$ & None & $\begin{array}{l}T .9 \mathrm{~cm} / \mathrm{\prime r} i \mathrm{ir} \\
100 \mu \mathrm{m} \\
3 \times 7.5 \mathrm{~cm} \\
\text { Semicont; } \\
\text { Cassette }\end{array}$ \\
\hline
\end{tabular}

Figure 3. Comparison of "Fast" Sheet Growth Processes Based on the Current Status of Productivity Parameters

The asterisk ( $\left.{ }^{*}\right)$ denotes the best current results.

\begin{tabular}{|c|c|c|c|c|}
\hline & $\begin{array}{l}\text { Impurliv } \\
\text { Sources }\end{array}$ & $\begin{array}{c}\text { linpurlty } \\
\text { Scgrcgation }\end{array}$ & $\begin{array}{c}\text { liinpuily } \\
\text { Redistribution }\end{array}$ & $\begin{array}{l}\text { Use of Low-Orade } \\
\text { Silicon Feedstock }\end{array}$ \\
\hline WEB & $\begin{array}{l}\text { Crucible }\left(\mathrm{SiO}_{2}\right) \\
\text { Heat shields (Mo) }\end{array}$ & $\begin{array}{l}k_{\text {eff }} \approx 1-3 k_{o} ; \\
k_{\text {eff }}<1 \text { with cont. } \\
\text { replenishment }\end{array}$ & None & $\begin{array}{l}\text { Grew from impure melt } \\
\text { (Fe, } \mathrm{Ti}, \mathrm{V}, \ldots . .) \text {; expect } \\
\text { most effect on growth }\end{array}$ \\
\hline RTR & $\begin{array}{l}\text { Microribbon } \\
\text { teedstock (Mo) }\end{array}$ & $\begin{array}{l}\text { Some zone } \\
\text { refinement; } \\
k \text { ęff }=-1\end{array}$ & $\begin{array}{l}\text { Possible with } \\
\text { interface shape } \\
\text { control }(w, t)\end{array}$ & $\begin{array}{l}\text { Unetched feedstock used; } \\
\text { expect some effect on } \\
\text { growth }\end{array}$ \\
\hline EFG & $\begin{array}{l}\text { Crucible }\left(\mathrm{SiO}_{2}, \mathrm{C}\right) \\
\text { Die (C) - } \\
\text { Cartridge }\end{array}$ & $k_{e f f}=1$ & $\begin{array}{l}\text { Controlled with" } \\
\text { die deslgn; } \\
\text { demonstrated }\end{array}$ & $\begin{array}{l}\text { mg-silicon feedstock } \\
\text { used; expect some effect } \\
\text { on growth }\end{array}$ \\
\hline soc & $\begin{array}{l}\text { Crucible }\left(\mathrm{SiO}_{2}\right) \\
\text { Mullite substrate }\end{array}$ & $k_{e f f}=1(?)$ & $\begin{array}{l}\text { Possible with } \\
\text { interface shape } \\
\text { control (t) }\end{array}$ & $\begin{array}{l}\text { No experience; expect } \\
\text { least effect on growth }\end{array}$ \\
\hline
\end{tabular}

Figure 4. Comparison of "Fast" Sheet Growth Processes Based on the Effects of Impurities

The ranking is based on best ultimate potential. The asterisk (") denotes best potential in a given area. 
techniques is the presence of thermal-stress-related buckles at the higher rates of growth. The morphological features of the sheets are important, of course, in view of their intended use as solar cell substrates.

\begin{tabular}{|c|c|c|c|}
\hline & Crystalline Structure & Conirol of Crystallinity & Sheet Morphology \\
\hline WEB & $\begin{array}{l}\text { Single crystal } \\
\text { Coplanar twins } \\
\{111\} \text { surface } \\
<10^{4} / \mathrm{cm}^{2} \text { dislocations }\end{array}$ & $\begin{array}{l}\text { Inherently good; Can grow } \\
\text { with extra dendrite or } \\
\text { poly }\end{array}$ & $\begin{array}{l}\text { Smooth } \\
\text { Some microsteps } \\
\text { Buckles }\end{array}$ \\
\hline EFG & $\begin{array}{l}\text { Polycrystal } \\
\text { Twins; Grain boundaries } \\
\text { Central grains } \\
\text { SiC particles } \\
\sim 10^{4} / \mathrm{cm}^{2} \text { dislocations }\end{array}$ & $\begin{array}{l}\text { Possible with interface } \\
\text { shape control (t); } \\
\text { Environment control } \\
\text { (Kalejs et al.)* }\end{array}$ & $\begin{array}{l}\text { Striations } \\
\text { Buckles } \\
\text { SiC particles }\end{array}$ \\
\hline RTR & $\begin{array}{l}\text { Polycrystal } \\
\text { Twins; Grain boundaries } \\
\text { G.B. near edges } \\
\text { Dendrites } \\
\sim 10^{5} / \mathrm{cm}^{2} \text { dislocations }\end{array}$ & $\begin{array}{l}\text { Possible with interiace } \\
\text { shape control }(t, w) \text {; } \\
\text { Lateral control } \\
\text { demonstrated }\end{array}$ & $\begin{array}{l}\text { Dendrites } \\
\text { Buckles }\end{array}$ \\
\hline soc & $\begin{array}{l}\text { Polycrystal } \\
\text { Twins; Grain boundaries } \\
\text { SiC near substrate } \\
10^{4}-10^{5} / \mathrm{cm}^{2} \text { dislocations }\end{array}$ & $\begin{array}{l}\text { Some possibility with } \\
\text { interface shape control (t) }\end{array}$ & $\begin{array}{l}\text { Mostly flat; } \\
\text { Effects of slotted } \\
\text { substrate }\end{array}$ \\
\hline
\end{tabular}

\section{Figure 5. Comparison of "Fast" Sheet Growth Processes Based on Considerations of Crystallinity}

The ranking is based on the best ultimate potential of the techniques.

\subsection{SOLAR CELL RESULTS}

The final ranking of "fast" sheet growth processes is based on their current status as solar cell substrates. The two sets of values in the efficiency and area columns of Fig. 6 refer to the best results (top) and the typically achieved values (bottom). The highest solar cell efficiencies have been shown in WEB material. The best experience with large area solar cells has been achieved with sheets produced using the EFG technique. EFG also ranks highest in the experiences with solar cell modules. Other columns in Fig. 6 list the typical air-mass-one (AM 1) solar cell values, the efficiency gaals for the various techniques, and some of the specific concerns in utilizing the sheet materials as solar cell substrates (e.g., handling- and fabrication-related problems). A major concern for all the techniques, with the possible exception of WEB, is the quality of the sheet material; high efficiency solar cells must be fabricated with a high yield in order to achieve the low-cost objectives. 


\begin{tabular}{|c|c|c|c|c|c|c|c|c|}
\hline & \multirow[b]{2}{*}{$\begin{array}{c}\text { Efficiency } \\
\text { (AM 1) }\end{array}$} & \multirow[b]{2}{*}{$\begin{array}{l}\text { Area } \\
\left(\mathrm{cm}^{2}\right)\end{array}$} & \multicolumn{3}{|c|}{ Typical Cell Parameters } & \multirow[b]{2}{*}{$\begin{array}{l}\text { Module } \\
\text { Results }\end{array}$} & \multirow{2}{*}{$\begin{array}{c}\text { Efficiency } \\
\text { Goal } \\
\text { (AM 1) }\end{array}$} & \multirow[b]{2}{*}{ Concerns } \\
\hline & & & $\begin{array}{l}V_{o c} \\
(\mathrm{mV})\end{array}$ & $\left|\begin{array}{c}\mathbf{J}_{\mathbf{s c}} \\
(\mathbf{m A} \mathbf{c m})\end{array}\right|$ & $F F$ & & & \\
\hline WEB & $\begin{array}{c}15.5 \% \\
12-13 \%\end{array}$ & $\begin{array}{c}1 \\
11 .\end{array}$ & 565 & 31 & 0.75 & $\begin{array}{c}0.1 \mathrm{~m}^{2} \\
\left(1 \mathrm{ft}^{2}\right) \\
11-12 \%\end{array}$ & $15 \%$ & Dendrites \\
\hline EFG & $\begin{array}{c}13-14 \% \\
10-11 \%\end{array}$ & $\begin{array}{c}10-50 \\
50\end{array}$ & 560 & 29 & 0.72 & $\begin{array}{l}0.4 \mathrm{~m}^{2} \\
\left(4 \mathrm{ft}^{2}\right) \\
9-10 \%\end{array}$ & $12 \%$ & Sheet quality \\
\hline RTR & $\begin{array}{c}13 \% \\
11-12 \%\end{array}$ & $\begin{array}{l}2 \\
4\end{array}$ & 390 & 20 & 0.74 & None & $14 \%$ & $\begin{array}{l}\text { Rigid edge } \\
\text { Shoot quality }\end{array}$ \\
\hline soc & $\begin{array}{c}10.1 \% \\
9 \%\end{array}$ & $\begin{array}{l}4 \\
4\end{array}$ & 560 & 24 & 0.74 & None & $11 \%$ & $\begin{array}{l}\text { Back conlacl } \\
\text { Sheet quality }\end{array}$ \\
\hline
\end{tabular}

\section{Figure 6. Comparison of "Fast" Sheet Growth Processes Based on the} Current Status of Solar Cell Results

The asterisk $\left(^{*}\right)$ denotes the best current results.

\section{GECTION 3.0}

\section{STATUS OP "PASTER" AND "PASTEST" RIBBON GROWTH TECHNIQUES}

The attainment of very rapid silicon sheet production rates has been of interest to several researchers in recent years; the motivation is, of course, to further reduce the cost of silicon substrates for photovoltaic applications. This section reviews the status of the novel technologies which have evolved and examines some of the problems which remain to be resolved.

\subsection{HORIZONTAL RIBBON GROWTH}

The "faster" growth rate in horizontal ribbon growth (see Fig. 1) results from the large area of the solid-liquid interface and the very close proximity of the interface to the heat loss surface. This leads to the very effective removal of the latent heat of solidification. Although the linear growth rates are quite high in this technique (up to $~ 100$ $\mathrm{cm} / \mathrm{min}$ ), the actual rate of growth of the crystal (i.e., rate of advance of the solid-liquid interface) is approximately the same as that ob tained using conventional silicon ingot growth techniques. Thus, horizontal ribbon growth offers the potential to produce high quality, single-crystal sheet material. 
The process of horizontal ribbon growth was originally envisioned (Bleil 1969) as the growth of a sheet from the top surface of a melt in a crucible. This technique for silicon sheet growth, however, has required a great deal of ing enuity in the design of the growth system (furnace and crucible). As far as the author is aware, two groups of researchers have been working in this area in recent years; their techniques are denoted as HRG and LASS in Fig. 7. The HRG process (Cullen and Surek 1980) has been under development for about four years and is at a more advanced stage than LASS, which has been under development for about a year (Jewett and Bates 1980). While HRG relies on active heating and cooling elements to control the growth, the emphasis in the LASS technique is on the design of passive thermal elements to stabilize the growth. Figure 7 shows some of the highlights in the development of these two techniques, as well as the values achieved for various growth and material para meters.

Several concerns need to be resolved before the potential of these techniques can be determined. The understanding of seeding and steady-state growth is generally inadequate. The processes involve relatively complex designs of the growth system, and they require very accurate controls of the temperature profiles and the melt level. The width and thickness uniformity of the ribbons is a concern. Wider and thinner ribbons need to be grown. The relative immaturity of these techniques is consistent, however, with the low levels of effort compared to the effort given to the "fast" sheet growth processes.

\subsection{MELT QUENCHING OR SPINNING}

Recent work on extremely rapid growth of silicon sheet has been reported by researchers at the Telecommunication Research Institute of Tohoku University (Tsuya et al. 1980). Termed "roller quenching" (see schematic in Fig. 1), the technique is based on existing commercial technologies for producing continuous ribbons of amorphous materials. Figure 8 summarizes the technique applied to silicon, the growth and material parameter results, and some of the major concerns. Note the simplicity of the technique (roller quenching in air), the extremely high growth rate $(30 \mathrm{~m} / \mathrm{s})$, and the preliminary solar cell results. Extensive eff orts will be required, however, to resolve the various problems.

\begin{tabular}{|c|c|c|c|c|c|c|c|}
\hline & $\begin{array}{c}\text { Technique } \\
\text { Development }\end{array}$ & $\begin{array}{l}\text { Width } \\
(\mathrm{mm})\end{array}$ & $\begin{array}{c}\text { Thickness } \\
(\mathbf{m m})\end{array}$ & $\begin{array}{l}\text { Length } \\
(\mathrm{cm})\end{array}$ & $\begin{array}{c}\text { Pate } \\
\text { (cm/min) }\end{array}$ & Crystallinity & $\begin{array}{l}\text { Electrical } \\
\text { Properties }\end{array}$ \\
\hline 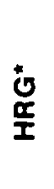 & $\begin{array}{l}\text { Crucible/furnace design; } \\
\text { Gas cooling; } \\
\text { Inclined growth }\left(<10^{\circ}\right) \text {; } \\
\text { Studies of seeding; } \\
\text { Melt replenishment }\end{array}$ & $\begin{array}{c}50(\max ) \\
10-30\end{array}$ & $\begin{array}{l}\begin{array}{l}0.2-0.35 \\
(\min ) \\
0.4-2\end{array} \\
0\end{array}$ & $>500$ & $\begin{array}{l}41.5 \\
85\end{array}$ & $\begin{array}{l}\text { Single } \\
\left(10^{5} / \mathrm{cm}^{2} \text { dlsl.) }\right. \\
\text { Poly }\end{array}$ & $\begin{array}{l}\text { Mobility, } \\
\text { lifetime com- } \\
\text { parable to CZ; } \\
\text { 9-10\% (AM 1, } \\
\text { no AR) }\end{array}$ \\
\hline $\begin{array}{l}0 \\
5 \\
5 \\
5\end{array}$ & $\begin{array}{l}\text { Crucible/furnace design; } \\
\text { Gas cooling; } \\
\text { Leading edge/lateral } \\
\text { stabilizers; } \\
\text { Low angle growth }\left(\sim 4^{\circ}\right) \text {; } \\
\text { Melt level control }\end{array}$ & $8-25$ & $0.3-1$ & 75 & $20-60$ & $\begin{array}{l}\text { Poly } \\
\text { No seeding } \\
>5-\mathrm{mm} \text { grains }\end{array}$ & Preliminary \\
\hline
\end{tabular}

* Horizontal Ribbon Growth (Japan Silicon Co.)

** Low Angle Silicon Sheet Growth (Energy Materials Corp.)

Figure 7. Status of "Faster" Sheet Growth Processes

Best (top), typical (bottom), and ranges of parameter values are indicated. 


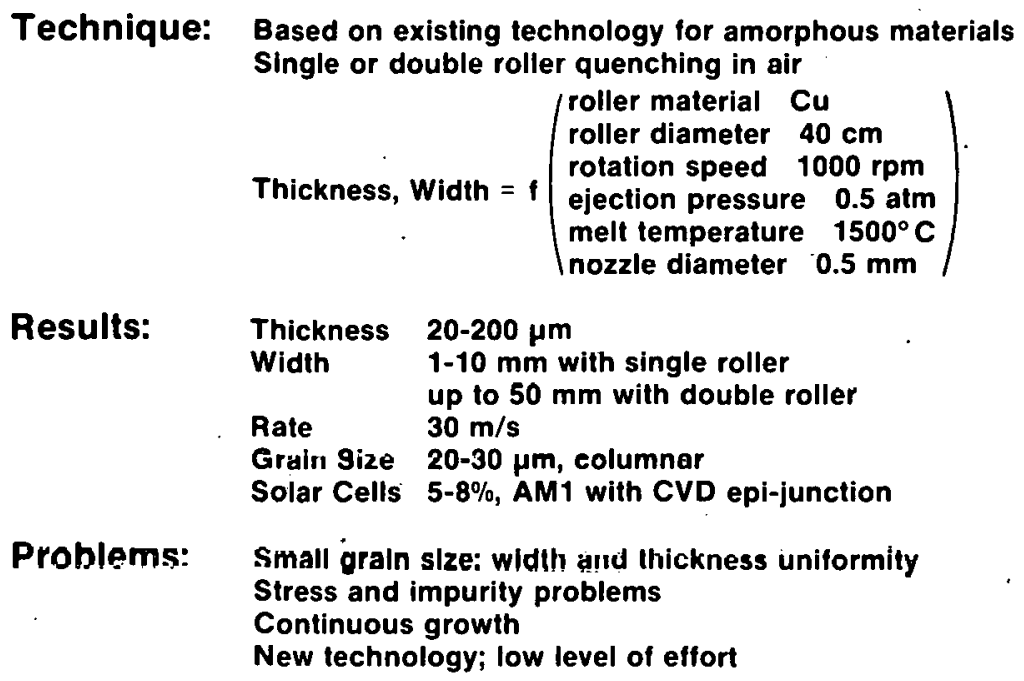

Source: Tsuya et al. 1980

Figure 8. Status of Silicon Ribbon Growth by Roller Quenching

\section{SECTION 4.0}

\section{SUMMARY.}

The development of silicon sheet growth processes has been truly remarkable over the past few years. A number of the techniques are nearly at the stage where their potential to meet the low-cost objectives for terrestrial photuvultaics can be fully demonstrated. This paper reviews and compares the so-called "fast" ribbon growth processes (EFG, WEB, SOC, and RTR), and identifies some of the problems that need to be resolved. Although there is good reason to expect that the objectives to achieve low-cost silicon photovoltaic systems. will be met, it is not possible to choose, in the author's opinion, among the various sheet growth processes at this time. This is especially true if one considers the results of the more rapid sheet growth techniques also reviewed in this paper, or the results of other novel sheet growth approaches reported recently such as the edgesupported pulling process described by Ciszck (Electrochemical Society 1 980). 


\section{SECTION 5.0}

\section{REFERENCES}

Bleil, C. E. 1969. J. Crystal Growth. Vol. 5: p. 99.

Cullen, G. W.; Surek, T.; eds. 1980. Shaped Crystal Growth, J. Crystal Growth. Vol. 50. Electrochemical Society. 1980. Proceedings of Symposium on Novel Silicon Growth Methods. New York: Electrochemical Society.

Jewett, D. N.; Bates, H. E. 1980. In Proc. 14th IEEE Photovoltaic Specialists Conference. New York: IEEE; p. 1404.

Tsuya, N.; Arai, K. I.; Takeuchi, T.; Ohmori, K.; Ojima, T.; Kuroiwa, A. 1980 J. Electron. Mater. Vol. 9: p. 111. 


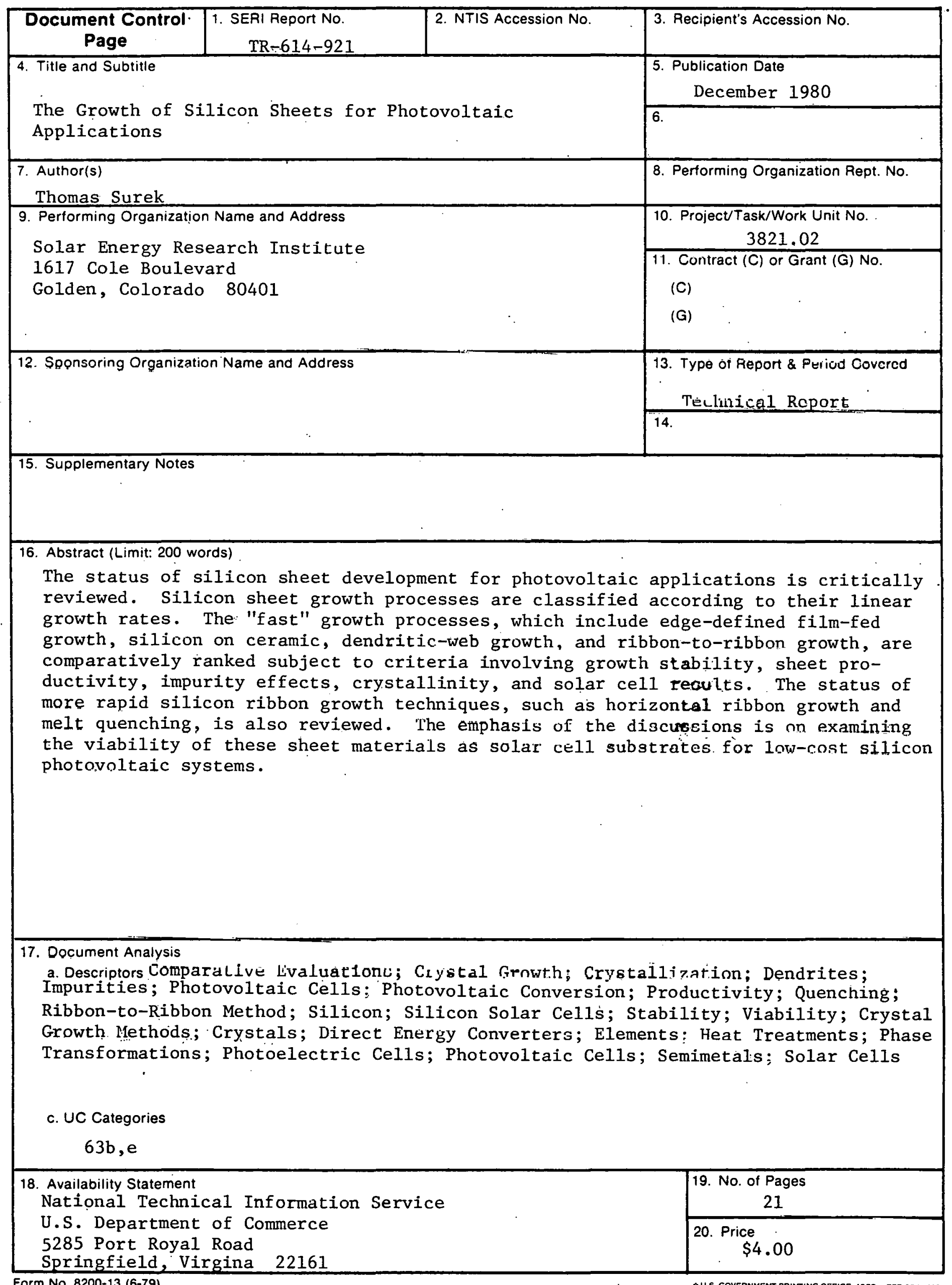

